\title{
An occupational therapy community of practice within pediatric acute care: fostering professional, social and cultural capital in resource challenged settings
}

\author{
Sandra Maria Galheigo ${ }^{a}$ (D), Claudia Pellegrini Braga ${ }^{a}$ (D), Lilian Magalhães ${ }^{b}$ (D), \\ Elizabeth Anne Kinsellac ${ }^{c}$ (D) \\ aDepartamento de Fisioterapia, Fonoaudiologia e Terapia Ocupacional, Universidade de São Paulo - USP, \\ São Paulo, SP, Brasil. \\ bDepartamento de Terapia Ocupacional, Universidade Federal de São Carlos - UFSCar, São Carlos, SP, Brasil. \\ ${ }^{\text {'S }}$ chool of Occupational Therapy, Faculty of Health Sciences, University of Western Ontário, London, ON, Canada.
}

\begin{abstract}
Introduction: The need to address the way professional knowledge is produced and delivered, has led some occupational therapy scholars to advocate for the creation of communities of practice (CoP) where practitioners may find a generative environment to engage in reflection with others, to collectively share their knowledge, and to develop professional practice knowledge. CoPs may result in the development of social capital by strengthening practitioners' social connections and advance cultural capital by improving collaborative forms of reflection and knowledge exchange. Objective: This article presents findings from a participatory action research project regarding the creation of a $(\mathrm{CoP})$ with the aim to implement and examine its affordances among pediatric occupational therapists working in acute care in a Brazilian context. Method: This participatory action research involved nine occupational therapists in 10 face-to-face meetings and in virtual interaction through an e-learning software platform. The community of practice group sessions were recorded, transcribed and coded. The hermeneutic and dialectic method was used as the basis for interpreting the results. Results: Five major themes concerning the affordances of the Occupational Therapy CoP in this context were identified: (i) dialogic engagement; (ii) reflective opportunities; (iii) a sense of belonging; (iv) affirming professional identity; (v) cultivating professional practice knowledge. Conclusion: Developing a CoP in occupational therapy may be a fruitful way to cultivate professional, social and cultural capital amongst occupational therapists who work in resource challenged settings.
\end{abstract}

Keywords: Occupational Therapy, Hospital Care, Knowledge, Attitudes, Professional Practice.

\section{Comunidade de prática de terapia ocupacional em cuidado hospitalar pediátrico: promovendo o capital profissional, social e cultural em contextos desafiadores}

Resumo: Introdução: A necessidade de abordar a forma como o conhecimento profissional é produzido tem levado estudiosos de terapia ocupacional a defenderem a criação de comunidades de prática $(\mathrm{CoP})$ nas quais os profissionais podem encontrar um ambiente facilitador para engajar-se em processos reflexivos, compartilhar coletivamente seus conhecimentos e desenvolver o conhecimento sobre a prática profissional. CoPs podem resultar no desenvolvimento do capital social através do fortalecimento de suas conexões sociais dos profissionais e aprimorar seu capital

Corresponding author: Sandra Maria Galheigo, Centro de Docência e Pesquisa em Fonoaudiologia, Fisioterapia e Terapia Ocupacional, Rua Cipotânea, 51, Cidade Universitária, CEP 05360-160, São Paulo, SP, Brasil, e-mail: sandramg@usp.br

Received on Nov. 9, 2018; $1^{\text {st }}$ Revision on Apr. 10, 2019; $2^{\text {nd }}$ Revision on May 23, 2019; Accepted on July 4, 2019.

This is an Open Access article distributed under the terms of the Creative Commons Attribution License, which permits unrestricted use, distribution, and reproduction in any medium, provided the original work is properly cited. 
cultural, ao favorecer modos de reflexão e troca de conhecimento. Objetivo: Este artigo apresenta os resultados de um projeto de pesquisa-ação referente à criação de uma CoP com o objetivo de implementar e examinar suas possibilidades entre terapeutas ocupacionais que trabalham junto a crianças hospitalizadas em um contexto brasileiro. Método: Esta pesquisa-ação envolveu nove terapeutas ocupacionais em 10 reuniões presenciais e em interação virtual por meio de uma plataforma de software de aprendizagem virtual. Os encontros da CoP foram gravados, transcritos e codificados. O método hermenêutico-dialético foi utilizado como base para interpretar os resultados. Resultados: Foram identificados cinco grandes temas referentes às oportunidades produzidas pela CoP nesse contexto: (i) engajamento dialógico; (ii) oportunidades reflexivas; (iii) sentido de pertencimento; (iv) afirmação da identidade profissional; (v) cultivo do conhecimento da prática profissional. Conclusão: O desenvolvimento de uma CoP na terapia ocupacional pode ser uma estratégia proveitosa de cultivar o capital profissional, social e cultural entre os terapeutas ocupacionais que trabalham em contextos desafiadores.

Palavras-chave: Terapia Ocupacional, Assistência Hospitalar, Conhecimento, Atitude, Prática Profissional.

\section{Introduction}

The nature of professional knowledge and the question about what takes precedence - theory or practice - have both been a matter of debate in the health professions (HIGGS; TITCHEN; NEVILLE, 2001) and in occupational therapy (MATTINGLY; FLEMING, 1994; TURPIN; IWAMA, 2011). The way professionals think while doing their practice has been predominantly understood as the application of scientific or technical knowledge to practice; what Schön referred to as technical rationality (KINSELLA, 2007; SCHÖN, 1987). In recent years, practitioner knowledge has also come to be viewed from a broader perspective that includes practical reasoning in context, in addition to scientific and technical knowledge:

It also involves drawing on understandings about one's own and others' intentions, understandings, meanings, values and interests, and on one's own and others' reflexive, unfolding understandings of the situation in which one is practicing at any given moment (KEMMIS, 2005, p. 392).

Thus, when practitioners solve practical problems or address situated demands they make use of scientific and technical knowledge, as well as their own practice-based experience by means of reflective judgments and interpretations (KEMMIS, 2005; KINSELLA, 2010).

Reflection however is not simply a monologic activity, it also occurs collaboratively in dialogue with others (KINSELLA, 2012). Kemmis (2005) points to dimensions of professional practice that cannot be captured exclusively within the individual realm. He notes that practice cannot be reduced to isolated acts performed by individuals who possess knowledge exclusively in their "heads" (KEMMIS, 2005, p. 391). Although professional practice has individual features, it is also a collective endeavour and an outcome of social and historical constructions. As Wenger (2008, p. 47) puts it: "[...] practice is always social practice". Practitioners engage in scenarios that are socially and historically situated, a fact that provides meaning and structure to practice as much as it contributes to shaping it (KEMMIS, 2005; WENGER, 2008). Practitioners encounter and respond to the needs, demands and expectations of others, regardless of whether they are service users, family members, other professionals or managers. They also inherit historical practices and discourses even if they are determined to transform those (KEMMIS, 2005). Action and practice take place in face-to-face or intersubjective encounters within a defined place and time - a context that enables a kind of intimacy and dialogue that is incorporated by the actors involved (e.g. users of services and practitioners) (KEMMIS, 2005). Therefore, it also demands justification:

This situated-ness and embodied-ness of practice where it meets people's lives means that there is a permanent demand for practice to justify itself to those it is intended to serve ('clients'), not only in terms of 'effectiveness' but also in terms of appropriateness (moral, social and historical) (KEMMIS, 2005, p. 413).

Health practitioners in their daily professional practices are required to justify their actions not only to service users and other members of the health team but to service administrators and professional associations. Within acute care settings, occupational therapy practitioners face similar challenges. Hospital care involves navigating public policy-making recommendations; constant technological advances; increasingly complex cases; and demands to cut healthcare costs (PETHYBRIDGE, 2004; GRIFFIN; MCCONNELL, 2001; ATWAL, 2002). Occupational 
therapy practitioners may face ethical tensions in trying to adapt to this ever-changing reality, without compromising their values (DUROCHER et al., 2016; ROBERTSON; FINLAY, 2007). Wilding and Whiteford (2007, p. 190) have suggested that tensions within the acute care work environment can leave occupational therapists with a sense of not belonging, noting that therapists in their study referred to themselves as "[...] a square peg in a round hole".

A further challenge is that the role of occupational therapists is not always recognized in acute care settings where biomedical rather than occupational or life world perspectives prevail. Wilding and Whiteford (2007, p. 185) have stressed the importance of occupational therapists knowing how to explain "[...] the valuable and unique contribution that occupational therapy makes to health care"; they assert that "[...] professional inaction contributes to political disadvantage in the increasingly competitive health sector". Taking such ideas seriously calls for activities that foster dialogue among members of the health team, service users, and family care-givers, to affirm occupational therapists' roles and the aims of treatment; a task that is not always easy, especially when therapists are impacted by power relations and a lack of professional capital within health care settings.

Differences in the power relations amongst professions may be a key factor in the cultivation of professional capital. Professional capital - an idea based on Bourdieu's constructs of social and cultural capital - has recently been considered in discussions about changes and challenges in various professions such as education (SERGIOVANNI, 1998), midwifery (BRODIE, 2003), nursing (CHAU, 2005), bioethics (GOLDENBERG, 2005) and social work (BEDDOE, 2013, 2017). Beddoe (2013) conceptualizes professional capital regarding the health social worker as:

A form of symbolic capital; where prestige, status and influence in both institutional life and the wider public discourse are important to social workers, because they perceive themselves as somehow lacking (BEDDOE, 2013, p. 53-54).

The challenges with professional capital illuminated in Beddoe's $(2013,2017)$ research with social workers are consistent with findings from a study with occupational therapists in Brazilian acute care settings (GALHEIGO; TESSUTO, 2010). In that study, participants reported feelings of professional isolation, a shortage of scholarly literature that could support the reality of their daily practices, perceptions of being undervalued by members of the health team, and complaints of low pay. These findings suggested that occupational therapists working in acute care settings may experience a tenuous environment in terms of professional capital (ie. social, cultural, symbolic and economic capital) (BOURDIEU, 1986). For instance, the fragile social organization of the profession in acute settings in Brazil implies a shortage of social capital; complaints about under sourced professional education suggests a deficit in cultural capital; feelings of devaluation signal insufficiencies in symbolic capital; and reference to low wages point to a shortfall in terms of economic capital. Furthermore, the participants were uneasy discussing the theoretical basis of their work suggesting another challenge for their professional capital. The therapists reported "hybridization" of the theoretical and methodological perspectives adopted and largely made use of examples and story-telling to show the complexities and features of their practice, further suggesting that the epistemological basis of their knowledge required explication (GALHEIGO; TESSUTO, 2010).

Beddoe's $(2013$, 2017) views on professional capital are informed by the work of Brodie (2003) and Chau (2005) who note that capital is revealed by recognition of a profession's value amidst related professional groups; they suggest professional capital can be improved by fostering trust, self-esteem and self-confidence, which in turn enables professionals to experiment with new learnings and to make changes to practice. Beddoe (2013, p. 56) highlights the importance of understanding professional capital as a renewable resource that can be

[...] applied to professional development and implies a continuing exposure to new knowledge. Given that the production of knowledge [...] is highly valued, then contributions to research and scholarship might be perceived to enhance professional capital further.

Beddoe's views on fostering professional capital hold resonance with ideas posed by some occupational therapy scholars who advocate for the creation of communities of practice where practitioners may find a generative environment to engage in reflection with others, to collectively share and cultivate professional knowledge, and to develop epistemic reflexivity. Epistemic reflexivity may be achieved when practitioners engage in reflection on "[...] the social conditions under which disciplinary knowledge comes into being and gains credence" 
and begin to view themselves as producers of practice-based knowledge rather than only as receivers of knowledge produced by researchers (KINSELLA; WHITEFORD, 2009, p. 250).

Developing professional capital becomes even more demanding in resource-challenged settings. Resource-challenged settings refer to health and social care contexts that call for the management of conditions and interventions with a significant lack of resources (CLEMONS; RAVELONANAHARY, 2009). In the health sector, this circumstance may imply low-access to primary health care, education, housing and sanitation, short supply of hospital care provisions and of funds to hire health professionals. Pediatric care is in high demand in resource-challenged settings, which endures high levels of morbidity and mortality. Child hospitalization is often needed in such settings due to reasons related to poor housing, insufficient sanitation, parental lack of basic education and inadequate primary health care coverage.

Although occupational therapy practice, as previously mentioned, faces daily difficulties at hospitals in highly industrialized societies, it encounters unique resource-challenges in countries such as Brazil, especially in acute pediatric care (BRASIL, 2018). Within this precarious context, occupational therapy services at hospitals are often understaffed, especially considering the large demand and the need to deal with challenges posed by unique social and health poverty-related conditions.

Given these issues, we reasoned that the development of a CoP could potentially contribute to the improvement of problem solving and reasoning by occupational therapists in acute pediatric care in resource-challenged settings in Brazil.

\section{Communities of Practice}

\section{Communities of practice are defined as}

[...] groups of people who share a concern, a set of problems, a passion about a topic, and who deepen their knowledge and expertise in this area by interacting on an ongoing basis (WENGER; MCDERMOTT; SNYDER, 2002, p. 4).

Communities of practice have been identified as offering benefits that may help practitioners mitigate the tensions between: theory and practice, technical rationality and lived experience, systemic constraints and therapeutic values, biomedical and occupational perspectives, individual and communal perspectives (BARRY et al., 2017; ROBERTS, 2015; REED; HOCKING, 2013; KIELHOFNER, 2005).
In Occupational therapy, several studies have reported on the use of CoPs to enhance occupational therapy practice (See Table 1). Various aims have been identified including: fostering collaborative dialogue and reflection; capacity building; and undertaking evaluation, dissemination and/or incorporation of novel concepts, models and theories (BAZYK et al., 2015; GALVIN; WILDING; WHITEFORD, 2011; GRAJO; CANDLER, 2017; REED; HOCKING, 2013; WILDING; CURTIN; WHITEFORD, 2012; WIMPENNY et al., 2010). Many CoPs use books as a stimulus to dialogue amongst $\mathrm{CoP}$ members (BAZYK et al., 2015; GALVIN; WILDING; WHITEFORD, 2011; GRAJO; CANDLER, 2017; REED; HOCKING, 2013; WILDING; CURTIN; WHITEFORD, 2012; WILDING; WHITEFORD, 2009). A study by Wilding and Whiteford (2009) aimed to foster reflection exclusively on therapists' daily professional experience with the objective of promoting change in acute hospital setting practices. Among studies in the occupational therapy literature, the intent of engaging participants in collaboration and change is prevalent, with several studies using collaborative or participatory action research (GALVIN; WILDING; WHITEFORD, 2011; REED; HOCKING, 2013; WILDING; CURTIN; WHITEFORD, 2012; WILDING; WHITEFORD, 2009; WIMPENNY et al., 2010). Furthermore, a few use mixed method designs with pretest/posttest and questionnaires, posted online discussions and/or focus groups (BAZYK et al., 2015; GRAJO; CANDLER, 2017; HOFFMANN; DESHA; VERRALL, 2011).

Regarding the use of a CoP in occupational therapy practice the literature identifies a number of potential benefits. Some aspects may result in the development of social capital by strengthening social connections such as: the development of social networks (HOFFMANN; DESHA; VERRALL, 2011); overcoming feelings of isolation (BAZYK et al., 2015; HOFFMANN; DESHA; VERRALL, 2011); reconnecting practitioners to OT's roots (BAZYK et al., 2015); creating opportunities for dialogue; fostering mutual learning (BAZYK et al., 2015); helping practitioners to obtain resources and information (HOFFMANN; DESHA; VERRALL, 2011); and discussing ideas and receiving feedback (HOFFMANN; DESHA; VERRALL, 2011). One study suggested that occupational therapists who participated in a CoP reported increases in their sense of autonomy, pride, satisfaction, professional confidence, passion and cohesion (WILDING; CURTIN; WHITEFORD, 2012). 


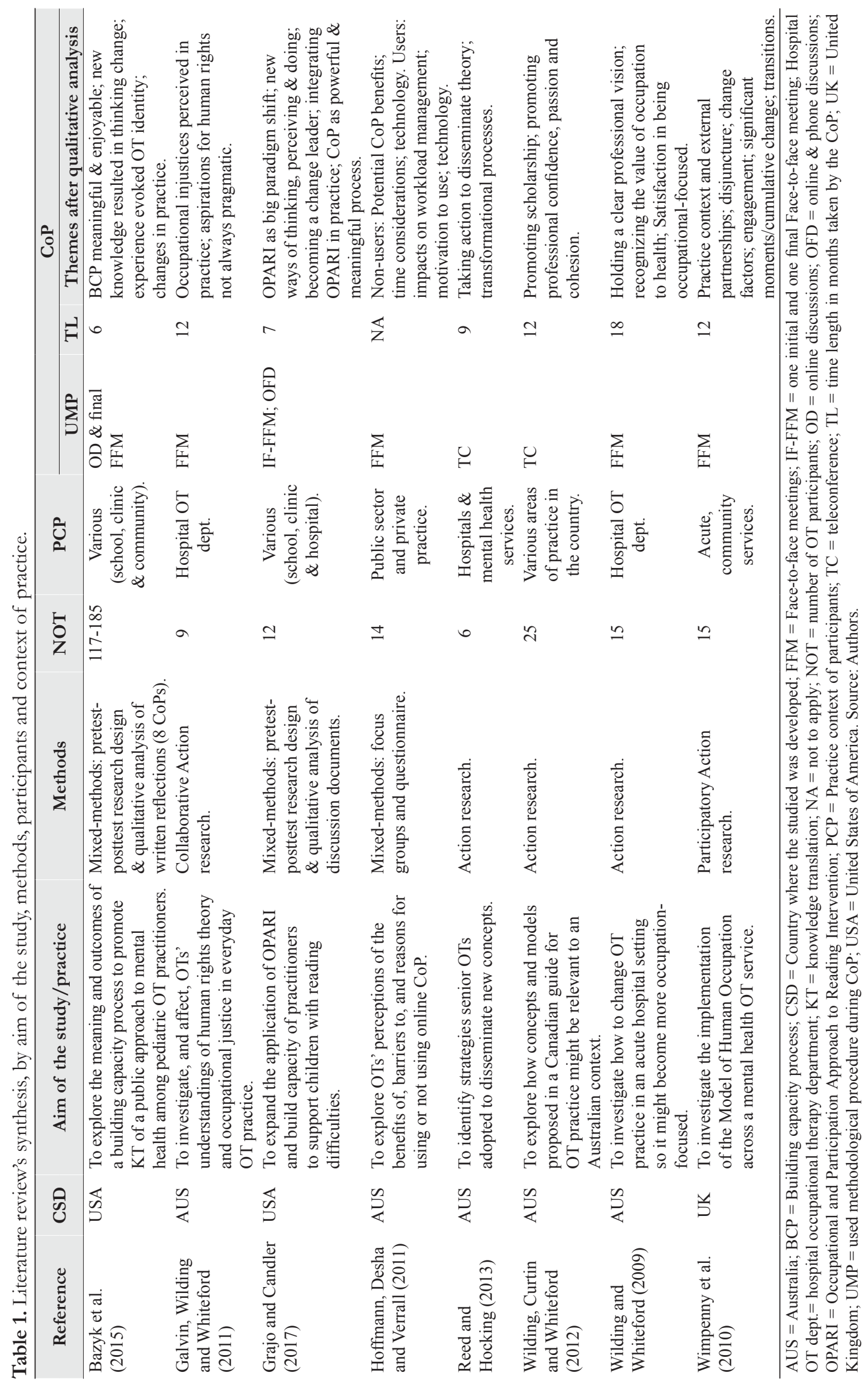


CoPs may also advance cultural capital; insofar as professional resources may be enhanced since advantages of CoPs have been related to the improvement of collaborative forms of reflection and knowledge exchange. For instance, CoPs have been described as a means to help participants to up-date knowledge; develop knowledge collectively; develop practical reasoning; engage in collaborative and dialogic reflection; and to make tacit practice-based knowledge explicit (REED; HOCKING, 2013; WILDING; CURTIN; WHITEFORD, 2012; WIMPENNY et al., 2010).

Studies have also demonstrated the importance of CoPs to broaden the epistemological basis of therapists' knowledge by: incorporating new knowledge through occupational perspectives. For instance, one occupationally focused CoP reframed views on mental health and enabled practitioners to focus on children's strengths, feelings and participation instead of on skill deficits (BAZYK et al., 2015). Another study addressed human rights theory and occupational justice philosophy in everyday occupational therapy practice (GALVIN; WILDING; WHITEFORD, 2011). Grajo and Candler (2017) highlighted a major paradigm shift towards a participatory approach with children with learning difficulties, while other studies showed how occupational perspectives offer alternative ways of framing clinical practice beyond biomedical understandings enabling capacities in practice and critical scholarship (HOFFMANN; DESHA; VERRALL, 2011; WILDING; CURTIN; WHITEFORD, 2012; WILDING; WHITEFORD, 2009).

Further, CoPs in occupational therapy have been identified as having the potential to enable a transformative process (REED; HOCKING, 2013) by: fostering exploration of topics beyond the area of interest and practice of practitioners (HOFFMANN; DESHA; VERRALL, 2011); facilitating the development of broader knowledge bases of OT practices (HOFFMANN; DESHA; VERRALL, 2011); and promoting new ways of thinking, perceiving and doing in practice (GRAJO; CANDLER, 2017). CoPs have also been identified as contributing to empowerment by supporting therapists to actively change practices in big and small ways, by increasing practitioner's practical knowledge, and through the renewed energy and confidence that practitioners may experience (BAZYK et al., 2015).

In summary, despite the effort required to create and sustain communities of practice (WILDING; CURTIN; WHITEFORD, 2012), the experience is frequently identified as a powerful and meaningful process (GRAJO; CANDLER, 2017) with the potential to revolutionize occupational therapy practice by creating dialogic spaces and opportunities for academic and practice collaborations (GALVIN; WILDING; WHITEFORD, 2011), and as a means to expand the epistemological basis of occupational therapy knowledge (WILDING; WHITEFORD, 2009; KINSELLA; WHITEFORD, 2009). This article presents findings from a participatory action research project regarding the creation of a $(\mathrm{CoP})$ with the aim to implement and examine its affordances among pediatric occupational therapists working in acute care in a resource-challenged Brazilian context.

\section{Methodology}

\subsection{Participatory Action Research (PAR)}

PAR was the chosen methodology for this $\mathrm{CoP}$ study since it embodies the idea of participation and change and, overall, implies a commitment to action (KEMMIS; WILKINSON, 1998; THIOLLENT, 1987). As Table 1 shows, PAR is a methodology that is highly suitable for research into CoPs. A precedent for the use of various forms of action research and participatory action research to study CoPs has been established in the occupational therapy profession (GALVIN; WILDING; WHITEFORD, 2011; REED; HOCKING, 2013; WILDING; CURTIN; WHITEFORD, 2012; WILDING; WHITEFORD, 2009; WIMPENNY et al., 2010). Further, PAR is an appropriate methodology to study professional practice and to attend to reflexivity; it involves a reflective spiral where change is planned, acted upon, observed, reflected on and re-planned, although not always following a neat cycle (KEMMIS; WILKINSON, 1998).

Kemmis and Wilkinson (1998), identify six key aspects of PAR that complement the aims of this study:

(i) PAR is a social process: it connects the individual and social dimensions;

(ii) PAR is participatory: it promotes the engagement of people in examining and interpreting their knowledge and actions;

(iii) PAR is practical and collaborative: it fosters social interaction;

(iv) PAR is emancipatory: it helps people to overcome oppressive structures and contributes to scrutiny of hegemonic discourses and practices; 
(v) PAR is critical: it helps people to overcome constraints produced by social media;

(vi) PAR is recursive: it promotes reflexive and dialectical thought and implies an immersion into a real context in order to change it.

PAR is not always an easy methodology to implement because of its unpredictability, and because designing the research, applying for funding and obtaining ethics clearance usually require identification of all procedures prior to action by the researchers. In this case, the research design needed to attend to the interests of the participants and offer opportunities for their engagement. PAR methodology presupposes that the participants are co-researchers of the process (THIOLLENT, 1987). The design of the study included a phase during which the invited participants came to understand their roles as co-researchers and co-facilitators of the CoP, while the lead researchers worked as facilitators of the ongoing process. This was not a straight forward practice and required the researchers to encourage the participants to understand and assume the new roles across the meetings. For example, the CoP members looked to the researchers to facilitate the process, whereas the researchers were working to hand over control of the process to the members.

\subsubsection{Recruitment and demographics}

The CoP involved nine occupational therapy co-researchers (CR), two lead researchers (LR) and two occupational therapy students (who provided practical and technical support). The co-researchers participated in the study and were recruited from hospitals in the city of São Paulo, Brazil, through a hospital survey and snowball sampling. They worked in pediatric practice: three in general hospitals; three in general children's hospitals; one in a burns unit; and two in pediatric oncology. Two were in their fifties, four in the thirties and three in the twenties. Two had between twenty-five and thirty years of professional experience; three between five and ten years and four participants up to five years. A guest discussant, a seasoned clinician and researcher, was an occasional member who took part in a few activities and was invited to bring more input to the discussions. Two research collaborators with international scholarly expertise in the field were also invited to consult on the project as it unfolded. They have contributed to further analysis and discussion of the material which resulted in this paper. The project had ethical clearance by the Medical School of the University of São Paulo, no 402/10 in 15/12/2010.

\subsubsection{Implementation of the community of practice group}

Informed consent was obtained at the beginning of the process. The implementation of the research involved two main activities: ten face to face CoP group meetings over seven months and a web-based platform where the co-researchers engaged in virtual activities, such as forums, chats, blogs, surveys, exchange of scholarly literature or other materials. The CoP groups were audio-recorded, filmed, and transcribed.

At the beginning the group was presented with potential topics for discussion, which were re-negotiated with input from participants, and re-confirmed at the end of each meeting. Among the themes discussed during the meetings were: professional experience in acute pediatric settings; assessment, therapeutic processes \& relationships in hospital care; intervention with families and care-providers. A major theme within the CoP was 'assessment' due to the participants' difficulties dealing with short-term hospital stays and unpredictable discharge, which afford a short window of opportunity to make decisions and provide interventions. The CoP enabled participants to reflect on the criteria they use to determine eligibility for treatment in their acute care contexts. Also, within the CoP, participants collaboratively developed a context-based assessment framework, which was informed by their practice experiences, and presented at national and international conferences and published by all the community members (GALHEIGO et al., 2017). An analysis of the lived process of participation in the CoP, discussed in the last COP meeting as the evaluation of the group participatory process, was also co-jointly published (GALHEIGO et al., 2015). The community members indicated that they most appreciated real-time dialogical gatherings, such as the face-to-face meetings and chats (GALHEIGO et al., 2015). Online blogs, writing of personal journals and other activities were resources that were only occasionally utilized.

\subsubsection{Data management and analysis}

The audio recordings of the meetings were transcribed and analysed by the primary researchers using line-by-line coding. The videos were used to clarify passages during the audio transcriptions process. They also allowed for other observations of the interactions between participants, which were discussed by the researchers after each meeting. The collected data resulted in approximately twenty 
hours of audio and videotaped recordings, resulting in three hundred and fifty pages of transcribed material. The final analysis resulted in six major themes, published separately due to space and word count constraints. As mentioned above, the participatory action process was discussed and analyzed separately by the CoP's members at the last meeting and later published in (GALHEIGO et al., 2015).

A hermeneutic dialectic method (MINAYO, 2014) was the framework used for data analysis. The hermeneutic method offers an approach to the interpretation of qualitative research (KINSELLA, 2006). It was used to direct attention to situated interpretations of participants' discursive exchanges, interpretations of various forms of textual materials, a critical analysis of the power relations within practices in hospital settings, and to examine contextual issues unique to resource-challenged settings.

The analysis produced for this paper required assessing transcriptions of the $\mathrm{CoP}$ groups by members of the research team and the international experts, with a focus on the affordances of the CoP process, as a means of knowledge production and exchange. The term affordances has emerged as a frequently used key word in health professional education and practice research, particularly over the past five years (VAN ENK; REGEHR, 2018; VEINOT et al., 2017). In addition, it is worth mentioning that the results presented here came most frequently from meetings one, three and four, and to a significant extent from meeting ten where the participants were invited to speak directly about their views on the experience of the CoP. Following quality criteria identified in the literature, the presentation of the findings aimed to 'show' rather than 'tell' the results (TRACY, 2010), and adopted thick description as a method, given the link to establishing credibility in qualitative research (GEERTZ, 1973, 1983; MORROW, 2005; TRACY, 2010).

It is important to note that the original transcripts were in Portuguese, and these excerpts have been translated into English to disseminate the research. However, language researchers have asserted that different ways of thinking and expressing ideas across cultures pose great challenges to research dissemination (ALASUUTARI, 2004). A Portuguese narrative will never be fully converted into English, despite all the measures to improve its effectiveness.

\section{Findings}

Concerning the affordances of the Occupational Therapy CoP process, five major themes were identified. These included: (i) dialogic engagement; (ii) reflective opportunities; (iii) a sense of belonging; (iv) affirming professional identity; and (v) cultivating professional knowledge.

\subsection{Dialogic engagement}

Throughout the various meetings, the participants engaged in dialogue about their practices and about what it means to be an occupational therapist in an acute setting. As the extract below demonstrates, at times an idea took form and gained momentum through dialogue.

CR1: I think when we take someone out of this environment [wards] you can better understand that person. [...] [We are saying]: "...I'm walking with you out here".

CR5: I see it in a different way. I think the hospital reality exists. I feel that this child is in that reality and it's not my job to suspend this reality, got it? My job is to help her to make some sense of this reality, to help her to elaborate that situation in order not to become so traumatized, stressed....

CR1: Um, I think that's the way it is. But, it's a unique relationship, right? You approach her in a way that is... different from other professionals. We do not focus on the disease.

CR4: I think... you both are discussing this. We [OTs] go there and ask, "But, who are you? What do you do? What do you miss...? Are you able to do what you want to do in here? What can we do to adapt something... to help you?". Hospital [life] is all about disrupting [everyday life]. I think we do this very delicate work to put things back together (Meeting 3).

The participants frequently engaged in dialogue to share stories about how they came to work in acute settings and their arrival at the hospital in which they were currently employed. Frequently, after the first few participants shared stories, the dialogue began to deepen into topics that may be perceived as more 'risky', or that involved critiques of systemic issues. As such, participants discussed challenging working conditions in acute care, lack of resources, and concerns about professional roles not being understood by members of the health team.

CR1: I do not know how you see it... I sometimes question my practice, [when other health professionals say]: "Hey, go there to talk to the occupational therapist who is going to do something different.... You're going to get out of it here, and stop thinking about your illness, ... your pain." 
I do not know how you feel about that, if this also happens to you.

CR5: Yes, several times, [they say to me]: "I have a case for you, a child hospitalized for more than 20 days who has begun to show some signs of hospitalization". In short: "You need to do something".

CR4: I lived it somewhat like that, "He's giving us a little trouble, can't you take a look, stay away with him for a while?", and I think this does not mean an authentic need [of this patient] (Meeting 3).

At times participants helped one another through dialogue to identify larger systemic issues that extend beyond the individual's interpretation of their own practice.

CR6: Right now the hospital is going through a certification process. Well, it interferes with [practice] sessions a lot, ... they talk a lot about quality, service, but then they ask you to do a lot of things and at the end you think "And the patient?"

CR1: The health professionals demand you a lot, one pulls you here, the other pushes you there. The management, as well.

CR4: I think you are talking about obstacles that make it difficult to build clinical reasoning because these are institutional demands, not the patients' (Meeting 1).

Participants frequently checked in with one another about their interpretations and experiences through phrases that open dialogue such as: "I don't know how you see it?" or "Actually, is it like that with you?" (Meeting 3, CR1).

Dialogue was revealed at times as a means-to share or make sense of partially formed interpretations or understandings.

CR2: I think the puzzle pieces are falling into place with this identification. Sometimes, I feel short of this or that [knowledge]; but I also contribute with what I'm thinking (Meeting 3).

The opportunity to speak with peers in the CoP was also frequently depicted through words such as 'valuable' 'fulfilling', a 'privilege':

CR2: This is the value... I feel grateful with the results so far... I feel fulfilled for the opportunity to speak... to seek identification with peers... it is so rich... I feel privileged to be taking part in this moment (Meeting 3).
Further pointing to the power of dialogue in the group, the possibility of hearing others' stories or having one's experiences heard was frequently pointed out as important:

CR5: This place of exchange, belonging, being with you, [this place] that I share, and hear the other. As I hear someone, scenes of practice sessions I was involved in emerge and I try to make sense of all that... (Meeting 10).

\subsection{Reflective opportunities}

Opportunities for reflection on practice and reflection with others emerged as an important way of participating in the CoP.

CR4: Can I just say something? [The reading] has a phrase that I think is very beautiful: occupational therapists tell stories of their patients and create stories with them. And I think that's it: by telling [stories], we start creating, making things [together] ... It's very beautiful.

CR3: And things are happening while we are telling, right? "This happened"; "He was doing that". Then you have another idea and go back there [to do something else with them]. It's interesting, indeed (Meeting 4).

The theme of reflection was also evident in participants' articulations of a desire to share clinical stories, and to reflect together on their practices.

CR1: I think we could experiment something here... performing a patient, an OT intervention. We could see the different approaches and deepen the debate further... to know people's practices...

CR5: Im keen to share clinical experience, lived situations.

CR4: I wish I could hear you all speaking more of the practice itself, I think that would be nice.

CR5: I want to speak of clinical experience and also to hear people telling how they conducted therapeutic processes. This is interesting, it is enriching, and it helps to name it [what we do] (Meeting 3).

CR1: We put things in practice, discussed [professional] daily life... a place of [shared] experience is very important to lead us to action (Meeting 10).

The possibilities of engaging in reflection as a way to generate practice-based knowledge or to make 
tacit knowledge more explicit was also discussed. As one participant put it:

CR3: This is where I wish this group would reach, that is [to grasp] the situations that are singular to the hospital care... to create the foundations for this practice [OT in acute care]. Then I think we will be less hindered (Meeting 1).

The power of reflection with others to change and inform action in day-to-day practice was also a prevalent theme. As one practitioner summed it up.

CR9: Exchanges... hearing about somebody's work and clinical experiences allows you to reflect on your own work, your day-to-day [practice], no matter if [the client] is a child, an adult or an elder (Meeting 10).

In the last group, one participant highlighted the comfort that she found through the sharing of reflections.

CR1: I think this was a place of reflection... in short, lived experience... an experiencing place ... comfort, talks (Meeting 10).

\subsection{A sense of belonging}

In the first meeting, various participants articulated a desire to share experiences, to understand the paths that practitioners are walking, and to connect with peers to discuss practice issues. As one participant summarized it:

CR2: We are aware of our limits. I think that now we are full of ideas... we are interested in discussing our practices... that we develop by the hospital bedsides... to understand the paths practitioners are walking... to find peers in these discussions... or at least find our own interest... (Meeting 1).

At the end of the process, several participants indicated that the community offered a place of belonging where professional practice could be discussed.

CR1: I think this was good for the group... this belonging... seeking a common identity for our professional practice in hospitals... (Meeting 10).

CR4: The professional life is difficult and demanding... I think the group is a place of integration... When I think of my process of belonging to this group I see the proposal [of the CoP] was very bold. When I say fulfilling I mean in relation to what I was living out there... this is a profession that is marvelous, and I do love it, but it is difficult to be an OT, isn't it? We are paid low wages and a lot is demanded, and I was questioning myself a lot about that... but suddenly, being here became very fulfilling (Meeting 10)

Despite differences in education and professional experience, the participants often linked the sense of belonging with the opportunity to share common identities as pediatric occupational therapists.

CR1: I recall the first meeting when we talked about our initiation to the hospital; I think this was the one that relieved me most from distress. When we left, we were moved by the fact that we had something in common - trajectories; despite the fact that we had different paths, education, length of experience, all of us had something in common (Meeting 10).

CR1: I think that we managed to reflect on our perception of the paths being constructed in our professional practice and this is related to our identity... Because although we have our own professional identity, it is always re-constructed... (Meeting 10).

\subsection{Affirming professional identity}

The process of the CoP was portrayed as gradually unfolding and seemed to contribute to an affirmation of professional identity.

CR4: This sense of lacking professional prestige has to be very well resolved ... we have to be aware of our professional role and the possibilities we have ... it is not a war of powers within the hospital. What I find most difficult is not dealing with medical power but being in the counter-hand of a biomedical perspective. You want that child to be recognized in another way, this has nothing to do with me as a professional, it has to do with how that child is understood beyond the cancer she has. This is the most difficult, and I believe it is a role for the occupational therapist and for that we must first work with ourselves (Meeting 1).

Processes of dialogue, respect for difference, constancy of the group, and tuning in to each other's 'language' were each named as supportive to the process.

CR4: We were glad to be different... for me to come to the group - "Oh... My God! What am I going to say? What a fear of saying something ... there are some people here more experienced than me!"... So, I needed time and constancy of coming to the meetings to become at ease with the others and to create a possibility of being together... In the 
beginning, we needed to tune into a common language since everyone was talking from a different place and I questioned myself: "What can I share, what can I bring here, what do I take from here?" (Meeting 10).

The consistency and persistency of the group was noted to contribute to participants' capacity to share with one another.

CR9: I believe that a word that can be used for this group is persistency. I think this group was able to be maintained...even [with people] missing meetings ... it never ceased to take place (Meeting 10).

In addition, participants spoke of the CoPs as enabling the collective identity of the group:

CR2: [The CoP] enabled me to develop an awareness of our collective construction that suggests material that is somewhat personal but is also of this group, of this area [of practice]; this is a legacy (Meeting 10).

Members also spoke about the ways that hearing their colleagues' stories of practice promoted good feelings about the work they do, fostering positive professional identities.

CR5: Many times I left the meetings with a good feeling about being an OT. This sharing and listening to other OTs doing OT made me think that it is good to be an OT and I believe this is related to identity... (Meeting 10).

\subsection{Enhancing professional practice knowledge}

Enhancing professional practice knowledge was another theme that emerged in the community of practice. Some participants discussed the isolation of working in acute settings, the lack of resources available to practitioners in the field, the inadequacy of their preparatory education, and the potential to learn through sharing of resources and experiences.

CR1: I think we are attracted to hospital work... it's a sort of a professional inclination too ... we find ourselves attracted to this very different environment compared to others... the environment, the standards, the dispositions, the ongoing relationships, the strategies. [...] We are not prepared for this at the university; [our knowledge] did not come from academia, not yet, but from experience. This [practical experience] favors this kind of reflection [we are doing] (Meeting 1).
CR1: When you leave the university, it looks like you miss it -the academic way - discussions, literature searches... when you are in practice, you get a bit isolated, you don't know what is happening. So, I said, "This is going be great, I'll get updated". When we had texts [to read] I would say - "Oh good I didn't miss it"... with daily practice you keep going or, rather, you keep with what you are used to seeing every day (Meeting 10).

Many participants noted that the CoP provided space to generate new knowledge and overcome the potential for stagnation in practice.

CR9: It cheered you up... the thinking. But we - who work solo in our day-to-day work-end up in stagnation, sameness. ...Meeting with [other] therapists is encouraging: "Ah, let me go after that, she talked about that, let me know it" (Meeting 10).

The potential to generate knowledge by sharing practice experiences was also frequently highlighted.

CR5: Listening and discussing about care, family care and therapeutic processes, is enriching and evidently this will bring a more careful and aware professional practitioner... [all] occupational therapists should participate in a group like that because it is enriching and transformative - we do not leave the way we joined it (Meeting 10).

Finally, the disjuncture between academia and clinical practice, or theory and practice, was an issue highlighted as a challenge for practitioners.

CR9: This brings up the issue of academia... who stay apart-but we need to get together ... clinical practice and academia (Meeting 10).

\section{Discussion}

\subsection{Professional capital}

The results of the study suggest that CoPs have the potential to offer affordances to occupational therapists through the cultivation of various forms of professional capital. The CoP offered opportunities for: the cultivation of dialogic spaces that allow for broader understandings of practice beyond the individual level; opportunities for engaging in collective forms of reflection; contributing to therapists' sense of belonging and thus mitigating isolation; affirming professional identity through shared stories of practice; and enhancing professional practice knowledge through sharing of resources and reflection on professional practice experiences. 
Consistent with the literature review previously presented, the results also suggest that CoPs may provide opportunities to strengthen of social connections, improve professional reflection, broaden professional knowledge, and enable transformative processes. The findings also support the proposition that CoPs have the potential to contribute to professional capital, by fostering attributes such as: mutually rewarding relationships amongst professionals; a sense of collective identity and self-esteem; and the ability to articulate "[...] knowledge-claims for practice and this requires both the application and production of knowledge" (BEDDOE, 2013, p. 57).

In the Brazilian context where various forms of 'capital' have been identified as a challenge for occupational therapists (GALHEIGO; TESSUTO, 2010), the CoP showed promise to enhance professional capital, and most particularly social and cultural forms of capital. This outcome also corroborates the results of previous research using $\mathrm{CoP}$ with occupational therapists in primary health care in Brazil (MARCOLINO et al., 2016). For Bourdieu (1986), capital is accumulated labour in a materialized or embodied form that depending on the field, as he names it, (i.e. education, media, health care, etc.), can hold different but intertwined semblances: economic capital, which translates into money and property rights; symbolic capital where prestige, status and influence in both institutional life and the wider public discourse are recognized; social capital, made of social connections and networks; and cultural capital, institutionalized in educational qualifications and professional expertise. The enhancement of the last two forms of capital - social and cultural capital - seemed to be particularly salient in terms of the affordances identified through participation in the CoP in the current study.

\subsection{Social capital}

Social capital was seen to be enhanced for occupational therapists in this study in various ways. It is defined by Bourdieu (1986, p. 51) as follows:

Social capital is the aggregate of the actual or potential resources which are linked to possession of a durable network of more or less institutionalized relationships of mutual acquaintance and recognition - or in other words, to membership in a group - which provides each of its members with the backing of the collectivity-owned capital, a 'credential' which entitles them to credit, in the various senses of the word. [...]. The volume of the social capital possessed by a given agent thus depends on the size of the network of connections he can effectively mobilize and on the volume of the capital (economic, cultural or symbolic) possessed in his own right by each of those to whom he is connected.

The CoP offered an opportunity to develop social capital through establishment of a network where participants exchanged knowledge through dialogue, engaged in collective reflection together, and experienced 'a sense of belonging'. Although the members of the community worked at hospitals in the same city they hardly knew each other prior to participation in the CoP. This suggests that CoPs may be a feasible way to develop social capital among occupational therapists, especially for those who work in isolation and do not have access to regular continuing education. The results suggest that policy and practice environments would be wise to consider how this sort of collective experience may enhance the capacities of practitioners in therapeutic practice, and potentially mitigate risks of burnout, staff changeover and attrition in the profession. Policy and practice guidelines should consider the affordances of creating opportunities for this type of professional engagement on a regular basis. The importance of building social capital was highlighted in the interest expressed by the members of the $\mathrm{CoP}$ in coming together, and participating in the project as co-researchers. The group overwhelmingly preferred face-to face meetings over individually based activities, or virtual activities that were not collaborative. In short, they preferred activities where dialogue and shared reflection could be established. This is consistent with Wenger's (2008) and Kemmis' (2005) argument that practice is always social and it is socially and historically situated; dialogue and collective forms of reflection are important to practice development.

\subsection{Cultural capital}

Cultural capital was also produced through the enhancement of professional practice knowledge reported in the CoP. Knowledge is a form of cultural capital in the sense that expertise may be traded for other goods, and has the potential to improve occupational therapists' capacities to carry out their work, develop expertise, and seek positions which offer enhanced remuneration.

For Bourdieu, the acquisition of cultural capital depends on the historical period, the society and social class and may take place regardless of conscious knowledge. It may also depend on resources invested by the family. 
The accumulation of cultural capital in the embodied state, i.e., in the form of what is called culture, cultivation, Bildung, presupposes a process of embodiment, incorporation, which, insofar as it implies a labor of inculcation and assimilation, costs time, time which must be invested personally by the investor. [...] The work of acquisition is work on oneself (self-improvement), an effort that presupposes a personal cost [...], an investment, above all of time, but also of that socially constituted form of libido, libido sciendi, with all the privation, renunciation, and sacrifice that it may entail (BOURDIEU, 1986, p. 48).

The CoP may offer a professional group an opportunity to enhance cultural capital collectively, through a collaborative and low-cost concerted effort, which has the potential to enhance practitioners' professional identity. Therapists frequently noted the validation they felt as occupational therapists as a result of engaging in the $\mathrm{CoP}$ process; a result that corroborates the findings of two previous studies of CoPs in occupational therapy (REED; HOCKING, 2013; WILDING; CURTIN; WHITEFORD, 2012). The findings also reaffirm the importance participants in CoPs express toward peer support and the value of connecting to each other to sustain professional identity (DERDALL; MULHOLLAND; BROWN, 2010; MARCOLINO et al., 2016).

\subsection{Symbolic and economic capital}

The production of symbolic capital, i.e., a capital that is "[...] apprehended symbolically, in a relationship of knowledge or, more precisely, of misrecognition and recognition" (BOURDIEU, 1986, p. 56) and economic capital, related to money and property rights, are also important forms of capital for occupational therapists; yet, they may be beyond the direct reach of CoPs. These may however be indirectly influenced by the development of social and cultural capital which may in turn create opportunities for increases in other forms of capital.

\section{Final Considerations}

The CoP provided space for the participants to engage in dialogue, reflect together, and to make sense of their practice experiences in collaborative ways. It worked as a strategy to engage participants in collective reflective practice (SCHÖN, 1987; KINSELLA, 2012), to stop-and-think (ARENDT, 1971) with others, about occupational therapy practice. It also offered opportunities for therapists to experience a sense of belonging and affirmation of their professional identities. Finally, it offered a location where therapists could enhance their professional practice knowledge through access to resources, and through sharing of practice-based experiences. The use of CoPs may be a fruitful way to contribute to the professional capital of occupational therapists, particularly the social and cultural capital of those who work in acute settings. CoPs may be especially salient as a means of building forms of professional capital for those working in resource challenged areas.

In considering the original contributions of this paper, it is important to highlight the novelty of identifying CoPs as means for the enhancement of professional, social and cultural capitals, a discussion seldom seen in the occupational therapy literature. Further little research has looked at the use of CoPs in settings with significant socio-political resource-challenges that extend beyond the institution. Further research should pursue this analysis in different geographical regions, especially in resource-challenged settings, or emergent areas of professional practice.

Limitations of the study may be related to the fact that the data was collected in Portuguese and translated and presented in English, which creates higher levels of interpretive challenge. Further, the participants did not report negative experiences in taking part in a CoP, beyond the challenges of time and transportation to the meetings. Further it is important to note that the findings are specific to a Brazilian context. Since social, cultural and political aspects play important roles in health care practices, the findings may be limited in their transferability to different countries, either affluent ones or resource challenged in distinctive ways.

\section{References}

ALASUUTARI, P. The globalization of qualitative research. In: GOBO, G. et al. (Org.). Qualitative research practice. Thousand Oaks: Sage, 2004. p. 595-608. http://dx.doi. org/10.4135/9781848608191.d41.

ARENDT, H. The life of the mind: thinking. New York: Harcourt Brace \& Jovanovich, 1971.

ATWAL, A. A world apart: how occupational therapists, nurses and care managers perceive each other in acute health care. British Journal of Occupational Therapy, London, v. 65, n. 10, p. 446-452, 2002. http://dx.doi. org/10.1177/030802260206501003.

BARRY, M. et al. Communities of practice: a means to support occupational therapists' continuing professional development: a literature review. Australian Occupational 
Therapy Journal, Melbourne, v. 64, n. 2, p. 185-193, 2017. http://dx.doi.org/10.1111/1440-1630.12334. PMid:27704565.

BAZYK, S. et al. Building capacity of occupational therapy practitioners to address the mental health needs of children and youth: a mixed-methods study of knowledge translation. American Journal of Occupational Therapy, Rockville, v. 69, n. 6, p. 1-10, 2015. http://dx.doi.org/10.5014/ ajot.2015.019182. PMid:26565099.

BEDDOE, L. A "profession of faith” or a profession: social work, knowledge and professional capital. New Zealand Sociology, Auckland, v. 28, n. 2, p. 44-63, 2013.

BEDDOE, L. Field, capital and professional identity: social work in health care. In: WEBB, S. Professional identity in social work. Oxon: Routledge, 2017. p. 122-135. http:// dx.doi.org/10.4324/9781315306957-9.

BOURDIEU, P. The forms of capital. In: RICHARDSON, J. Handbook of theory and research for the sociology of education. New York: Greenwood, 1986. p. 241-258.

BRASIL. Politica Nacional de Atenção Integral à Saúde da Criança: orientaçóes para implementação. Brasília: Ministério da Saúde, 2018.

BRODIE, P. The invisibility of midwifery: will developing professional capital make a difference? 2003. $344 \mathrm{f}$. Thesis (Doctorate of Midwifery) - Sydney University of Technology, Sydney, 2003.

CHAU, C. Professional capital: an informational approach to nursing. In: KNOWLEDGE MANAGEMENT: NURTURING CULTURE, INNOVATION, AND TECHNOLOGY, 2005, Singapore. Proceedings... Singapore: World Scientific Publishing, 2005. p. 671-673. Available from: <https://www.worldscientific.com/doi/pdf/10.1 142/9789812701527_0059>. Access on: 1 Sept. 2019.

CLEMONS, A.; RAVELONANAHARY, M. What does resource-challenged mean according to educators and educational researchers? A review of the literature relevant to textbooks and education media in Madagascar. Iartem E-Journal, Denmark, v. 2, n. 1, p. 1-12, 2009.

DERDALL, M.; MULHOLLAND, S.; BROWN, C. Evaluating students' use of web-based communication during practice placements. British Journal of Occupational Therapy, London, v. 73, n. 10, p. 457-460, 2010. http:// dx.doi.org/10.4276/030802210X12865330218221.

DUROCHER, E. et al. Ethical tensions related to systemic constraints: occupational alienation in occupational therapy practice. OTJR: Occupation Participation \& Health, Thorofare, v. 36, n. 4, p. 216-226, 2016. http://dx.doi. org/10.1177/1539449216665117. PMid:27591435.

GALHEIGO, S. M. et al. Comunidade de prática em terapia ocupacional: a avaliação do processo pelos participantes e pelos pesquisadores. Cadernos de Terapia Ocupacional da UFSCar, São Carlos, v. 23, n. 3, p. 463-474, 2015. http:// dx.doi.org/10.4322/0104-4931.ctoAO0471.
GALHEIGO, S. M. et al. Exchanging knowledge within a community of practice: toward an epistemology of practice in occupational therapy paediatric hospital care. Cadernos Brasileiros de Terapia Ocupacional, São Carlos, v. 25, n. 3, p. 449-459, 2017. http://dx.doi.org/10.4322/2526-8910. ctoAO1119.

GALHEIGO, S. M.; TESSUTO, L. Trajetórias, percepções e inquietaçóes de terapeutas ocupacionais do Estado de São Paulo no âmbito das práticas da terapia ocupacional no hospital. Revista de Terapia Ocupacional da Universidade de São Paulo, São Paulo, v. 21, n. 1, p. 23-32, 2010. http:// dx.doi.org/10.11606/issn.2238-6149.v21i1p23-32.

GALVIN, D.; WILDING, C.; WHITEFORD, G. Utopian visions/dystopian realities: exploring practice and taking action to enable human rights and occupational justice in a hospital context. Australian Occupational Therapy Journal, Melbourne, v. 58, n. 5, p. 378-385, 2011. http://dx.doi. org/10.1111/j.1440-1630.2011.00967.x. PMid:21957923.

GEERTZ, C. The interpretation of cultures: selected essays. New York: Basic Books, 1973.

GEERTZ, C. Local knowledge: further essays in interpretive anthropology. New York: Basic Books, 1983.

GOLDENBERG, M. Evidence-based ethics? On evidencebased practice and the "empirical turn" from normative bioethics. BMC Medical Ethics, London, v. 6, n. 1, p. 1-9, 2005. http://dx.doi.org/10.1186/1472-6939-6-11. PMid:16277663.

GRAJO, L. C.; CANDLER, C. The Occupation and Participation Approach to Reading Intervention (OPARI): a community of practice study. Journal of Occupational Therapy Schools and Early Intervention, Tacoma, v. 10, n. 1, p. 90-99, 2017. http://dx.doi.org/10.1080/19411243 .2016 .1257967 .

GRIFFIN, S.; MCCONNELL, D. Australian occupational therapy in acute care settings. Occupational Therapy International, London, v. 8, n. 3, p. 184-197, 2001. http:// dx.doi.org/10.1002/oti.145. PMid:11823882.

HIGGS, J.; TITCHEN, A.; NEVILLE, V. Professional Practice and Knowledge. In: HIGGS, J.; TITCHEN, A. Practice knowledge and expertise in the health professions. Oxford: Butterworth-Heinemann, 2001. p. 3-9.

HOFFMANN, T.; DESHA, L.; VERRALL, K. Evaluating an online occupational therapy community of practice and its role in supporting occupational therapy practice. Australian Occupational Therapy Journal, Melbourne, v. 58, n. 5, p. 337-345, 2011. http://dx.doi.org/10.1111/j.14401630.2011.00954.x. PMid:21957918.

KEMMIS, S. Knowing practice: searching for saliences. Pedagogy Culture and Society, United Kingdom, v. 13, n. 3, p. 391-426, 2005. http://dx.doi.org/10.1080/14681360500200235.

KEMMIS, S.; WILKINSON, M. Participatory action research and the study of practice. In: ATWEH, B.; KEMMIS, S.; WEEKS, P. Action research in practice: partnerships for social justice in education. London: Routledge, 1998. p. 21-36. 
KIELHOFNER, G. A scholarship of practice: creating discourse between theory, research and practice. Occupational Therapy in Health Care, New York, v. 19, n. 1-2, p. 7-16, 2005. http://dx.doi.org/10.1080/J003v19n01_02. PMid:23927698.

KINSELLA, E. A. Hermeneutics and critical hermeneutics: exploring possibilities within the art of interpretation. Forum: Qualitative Social Research, New York, v. 7, n. 3, p. 1-11, 2006.

KINSELLA, E. A. Technical rationality in Schön's reflective practice: dichotomous or non-dualistic epistemological position. Nursing Philosophy, Oxford, v. 8, n. 2, p. 102-113, 2007. http://dx.doi.org/10.1111/j.1466-769X.2007.00304.x. PMid:17374071.

KINSELLA, E. A. Professional knowledge and the epistemology of reflective practice. Nursing Philosophy, Oxford, v. 11, n. 1, p. 3-14, 2010. http://dx.doi.org/10.1111/j.1466769X.2009.00428.x. PMid:20017878.

KINSELLA, E. A. Practitioner reflection and judgement as phronesis. In: KINSELLA, E. A.; PITMAN, A. Phronesis as professional knowledge. Rotterdam: Sense Publishers, 2012. p. 35-52. http://dx.doi.org/10.1007/978-94-6091-731-8_3.

KINSELLA, E. A.; WHITEFORD, G. Knowledge generation and utilisation in occupational therapy: towards epistemic reflexivity. Australian Occupational Therapy Journal, Melbourne, v. 56, n. 4, p. 249-258, 2009. http://dx.doi. org/10.1111/j.1440-1630.2007.00726.x. PMid:20854525.

MARCOLINO, T. Q. et al. Comunidade de prática em terapia ocupacional para o cuidado em saúde mental na atenção básica em saúde: expectativas e impactos. Cadernos de Terapia Ocupacional da UFSCar, São Carlos, v. 24, n. 4, p. 733-741, 2016. http://dx.doi.org/10.4322/01044931.ctoAO0788.

MATTINGLY, C.; FLEMING, M. Clinical reasoning: forms of inquiry in a therapeutic practice. Philadelphia: Davis Company, 1994.

MINAYO, M. C. S. O desafio do conhecimento: pesquisa qualitativa em saúde. São Paulo: Hucitec, 2014.

MORROW, S. Quality and trustworthiness in qualitative research in counseling psychology. Journal of Counseling Psychology, Washington, v. 52, n. 2, p. 250-260, 2005. http://dx.doi.org/10.1037/0022-0167.52.2.250.

PETHYBRIDGE, J. How team working influences discharge planning from hospital: a study of four multidisciplinary teams in an acute hospital in England. Journal of Interprofessional Care, Abingdon, v. 18, n. 1, p. 29-41, 2004. http://dx.doi.org/10.1080/13561820410001639 334. PMid:14668100.

REED, K.; HOCKING, C. Re-visioning practice through action research. Australian Occupational Therapy Journal, Melbourne, v. 60, n. 3, p. 181-188, 2013. http://dx.doi. org/10.1111/1440-1630.12033. PMid:23730783.

ROBERTS, G. Communities of practice: exploring enablers and barriers with school health clinicians. Canadian Journal of Occupational Therapy, Ottawa, v. 82, n. 5, p. 294-306, 2015. http://dx.doi.org/10.1177/0008417415576776. PMid:26590229.

ROBERTSON, C.; FINLAY, L. Making a difference, teamwork and coping: the meaning of practice in acute physical settings. British Journal of Occupational Therapy, London, v. 70, n. 2, p. 73-80, 2007. http://dx.doi. org/10.1177/030802260707000205.

SCHÖN, D. Educating the reflective practitioner. San Francisco: Jossey-Bass, 1987.

SERGIOVANNI, T. J. Leadership as pedagogy, capital development and school effectiveness. International Journal of Leadership in Education, Texas, v. 1, n. 1, p. 37-46, 1998. http://dx.doi.org/10.1080/1360312980010104.

THIOLLENT, M. Notas para o debate sobre pesquisa-ação. In: BRANDÃO, C. R. Repensando a pesquisa participante. Sáo Paulo: Brasiliense, 1987. p. 82-103.

TRACY, S. J. Qualitative quality: eight “big-tent” criteria for excellent qualitative research. Qualitative Inquiry, Bradford, v. 16, n. 10, p. 837-851, 2010. http://dx.doi. org/10.1177/1077800410383121.

TURPIN, M. J.; IWAMA, M. K. Using occupational therapy models in practice: a field guide. London: Elsevier Health Sciences, 2011.

VAN ENK, A.; REGEHR, G. HPE as a field: implications for the production of compelling knowledge. Teaching and Learning in Medicine, Hillsdale, v. 30, n. 3, p. 337-344, 2018. http://dx.doi.org/10.1080/10401334.2017.1392 864. PMid:29240451.

VEINOT, P. et al. Faculty and resident perspectives on ambulatory care education: a collective case study of family medicine, psychiatry, and surgery. Canadian Medical Education Journal, Ottawa, v. 8, n. 3, p. e37-e48, 2017. PMid:29098047.

WENGER, E. Communities of practice: learning, meaning and identity. Cambridge: Cambridge University Press, 2008.

WENGER, E.; MCDERMOTT, R.; SNYDER, W. Cultivating communities of practice: a guide to managing knowledge. Boston: Harvard Business School Press, 2002.

WILDING, C.; CURTIN, M.; WHITEFORD, G. Enhancing occupational therapists' confidence and professional development through a community of practice scholars. Australian Occupational Therapy Journal, Melbourne, v. 59, n. 4, p. 312-318, 2012. http://dx.doi. org/10.1111/j.1440-1630.2012.01031.x. PMid:22934904.

WILDING, C.; WHITEFORD, G. Occupation and occupational therapy: knowledge paradigms and everyday practice. Australian Occupational Therapy Journal, Melbourne, v. 54, n. 3, p. 185-193, 2007. http://dx.doi. org/10.1111/j.1440-1630.2006.00621.x.

WILDING, C.; WHITEFORD, G. From practice to praxis: reconnecting moral vision with philosophical underpinnings. British Journal of Occupational Therapy, 
London, v. 72, n. 10, p. 434-441, 2009. http://dx.doi. org/10.1177/030802260907201004.

WIMPENNY, K. et al. Implementing the model of human occupation across a mental health occupational therapy service: communities of practice and a participatory change process. British Journal of Occupational Therapy, London, v. 73, n. 11, p. 507-516, 2010. http://dx.doi.org/10.427 6/030802210X12892992239152.

\section{Author's Contributions}

Sandra Maria Galheigo and Claudia Pellegrini Braga had both designed and develop the research. Lilian Magalhães and Elizabeth Anne Kinsella had both colaborated in the discussion of results. All of them took part in the writing of the manuscript. All authors approved the final version of the text.

\section{Funding Source}

This research was made possible by the support of the São Paulo Research Foundation - FAPESP, Brazil, grant $n^{\circ}$ 2010/19718-0 and by the International Cooperation FAPESP, Brazil/Western University, Canada, grant no 2011/51766-8. 